\title{
Post-harvest deterioration of banana fruits and its control using fungicides
}

KEDAR NATH ${ }^{1}$, K.U. SOLANKY ${ }^{1}$, MADU BALA ${ }^{2}$ AND G.L. KUMAWAT*3

${ }^{1}$ Department of Plant Pathology, N.M. College of Agriculture, Navsari Agricultural University, NAVSARI (GUJARAT) INDIA.Email: kd_path2005@yahoo.co.in

${ }^{2}$ Department of Plant Breeding and Genetics, N.M. College of Agriculture, Navsari Agricultural University, NAVSARI (GUJARAT) INDIA

${ }^{3}$ Division of Floriculture and Landscaping, Indian Agricultural Research Institute, Pusa, NEW DELHI, INDIA

\section{ARITCLE INFO}

Received : 07.05 .2014

Revised : 29.07 .2014

Accepted : 15.08 .2014

\section{KEY WORDS :}

Banana, Fungicides, Fungi, Post

harvest deterioration

\begin{abstract}
Post-harvest deterioration is the most important cause of loss in banana production and this is mainly as a result of microbial invasion of the fruits. This research was therefore carried out to identify and control the fungal organism responsible for post-harvest deterioration of banana fruits. Mancozeb, carbendazim, propiconazole and SAAF at tested concentration were used as antifungal agents and the susceptibility of four, of the isolated major pathogenic fungi to them was observed in culture. The tested organisms were Lasiodiplodia theobromae Pat.Griffth and Maubl, Fusarium moniliformae Sheld, Fusarium sp. and Aspergillus niger van Tiegh. Maximum disease control of 98.76 per cent and 98.67 per cent of fruit rot was observed in propiconazole and SAAF treated fruits, respectively followed by carbendazim $(96.79 \%)$ under storage condition up to eating ripe stage.
\end{abstract}

How to view point the article : Nath, Kedar, Solanky, K.U., Bala, Madu and Kumawat, G.L. (2014). Post-harvest deterioration of Banana fruits and its control using fungicides. Internat. J. Plant Protec., 7(2) : 345-348. 